\title{
Performance of off season bell pepper (Capsicum annuum L.) under different growing condition, transplanting dates and pruning level
}

\section{Ranjit Chatterjee}

Department of Vegetable and Spice Crops, Uttar Banga Krishi Viswavidyalaya, Pundibari, Cooch Behar (West Bengal), India

\section{Aradhana Sen*}

Department of Vegetable and Spice Crops, Uttar Banga Krishi Viswavidyalaya, Pundibari, Cooch Behar (West Bengal), India

\section{Sandip Mahanta}

Department of Vegetable and Spice Crops, Uttar Banga Krishi Viswavidyalaya, Pundibari, Cooch Behar (West Bengal), India

\section{Ravi kiran Thirumdasu}

Department of Vegetable and Spice Crops, Uttar Banga Krishi Viswavidyalaya, Pundibari, Cooch Behar (West Bengal), India

\section{Dipika Mal}

Department of Vegetable and Spice Crops, Uttar Banga Krishi Viswavidyalaya, Pundibari, Cooch Behar (West Bengal), India

*Corresponding author. E-mail: nini.sen20@gmail.com

\begin{abstract}
Bell pepper fruits fetches higher premium during early winter or late winter as off-season crops. An experiment was conducted during late winter (February to June) of 2013 at Uttar Banga Krishi Viswavidyalaya, Pundibari, West Bengal, India to compare the performance of bell pepper (Capsicum annuum L.) in open field and agro shade net under different transplanting dates and pruning level which was laid out in split split plot design with 3 replications. The results revealed that agro shade net cultivation of bell pepper emerged as best in terms of highest plant height $(52.42 \mathrm{~cm})$, and higher number of fruit (11.18 plant $\left.^{-1}\right)$. The interaction effect combining shade net cultivation with $1^{\text {st }}$ February planting date coupled with 3 shoot pruning proved superiority with respect to growth and yield characters of bell pepper and resulted in many fold improvement in the form of higher fruit number (16.21 plant $\left.^{-1}\right)$, individual fruit weight $(107.54 \mathrm{~g})$ and maximum fruit yield $\left(1743.21 \mathrm{~g} \mathrm{plant}^{-1}\right)$.
\end{abstract}

Keywords: Agro-shade net, Open field, Planting dates, Pruning levels

\section{INTRODUCTION}

Bell pepper (Capsicum annuum L.) is a high value low volume winter season cash crop and fetches higher price during early winter or late winter as off-season crops. The fresh fruit consumed as salad or cooked as vegetable is rich in antioxidants, vitamin $A$ and vitamin $C$ which protects human body from oxidative damages that may lead to heart disease, cancer and ageing. The crop is highly sensitive to environmental stresses particularly temperature. High day as well as night temperatures prompted flower drop and reduced fruit set in bell pepper (Rylski and Halevy, 1974; Erickson and Markhart, 2001). Turner and Wien, (1994) stated that physiological changes occur within the plant system like decrease in sugar content and lower enzymatic activities which encourage abnormal pollen and another develop-

\section{Article Info}

DOI:10.31018/jans.v10i3.1721

Received: May 8, 2018

Revised: June 11, 2018

Accepted: June 20, 2018

\section{How to Cite}

Chatterjee, R. et al. (2018). Performance of off season bell pepper (Capsicum annuum L.) under different growing condition, transplanting dates and pruning level. Journal of Applied and Natural Science, 10 (3): $826-830$ ment, resulting in decrease in pollen viability, pollen tube growth and abortion of buds, flowers and young fruits. The winter crop is blessed with favourable climate and produced higher fruit yield but fail to attract premium price due to plenty of supply and market glut. The off-season bell pepper during late winter fetches higher remuneration as price remains very high and adverse climate causes decline in production or even crop failure. Due to erratic behaviour of weather the late winter crop grown in open field are often exposed to fluctuating levels of temperature, humidity, light intensity, wind flow etc. which adversely affect the crop productivity (Jovicich et al., 2005).

With the introduction of agro-shade net the growers can raise the winter crops during early summer months (Chatterjee and Mahanta, 2013) as the structure partially controls the temperature and light and creates a favourable environment for the 
crop. To permit closer planting, early ripening of fruits and to get higher yields plants are pruned either to a single stem or two stems or three stems. However, in bell pepper pruning levels influences the fruit setting and total fruit yield (Zende, 2008). Meagre information is available on response of different pruning level on shade net bell pepper and there is an urgent need to assess the optimum pruning level to maximise fruit yield. The present work was formulated to compare the plant growth, yield and quality attributes of bell pepper (Capsicum annuum L.) under open field and agro shade net house on different planting dates and to identify the optimum pruning level for maximization of fruit yield and quality to make the production system viable and remunerative.

\section{MATERIALS AND METHODS}

The study was carried out at the Instructional Farm of UBKV, Pundibari, Cooch Behar, West Bengal, India during late winter (February to June) of 2013 . The site is located at $89^{\circ} 23^{\prime} 53^{\prime \prime}$ E longitude and $26^{\circ} 19^{\prime} 86^{\prime \prime} \mathrm{N}$ latitude and at $43 \mathrm{~m}$ above mean sea level. The soil was sandy loam $(66 \%$, $24 \%$ and $20 \%$ sand, silt and clay respectively) in texture obtained by International Pipette Method (Piper, 1950) and slight acidic in reaction ,pH 5.74 (Baruah and Barthakur, 1997). The initial soil organic carbon was $0.87 \%$ (Rapid titration method by Walkley and Black,1934) and available $\mathrm{N}$ (Modified Macro Kjeldahl method by Jackson,1967), P (Bray's No. I Method by Jackson, 1967) and K (Flame photometer method by Jackson, 1967)contents were 174.06, 21.27 and $122.51 \mathrm{~kg} \mathrm{ha}^{-1}$ respectively. The treatments comprised of 2 growing condition (open field and agro shade net house), 4 planting dates $\left(1^{\text {st }}\right.$ February, $15^{\text {th }}$ February, $2^{\text {nd }}$ March and $17^{\text {th }}$ March) and 4 pruning level (no pruning, 2 shoot pruning, 3 shoot pruning and 4 shoot pruning). Thus 32 treatment combinations were laid out in split split plot design with 3 replications. An ultraviolet (UV) stabilized high density polyethylene (HDPE) naturally ventilated green agro shade net house of $20 \times 10 \mathrm{~m}$ dimension with $50 \%$ shade intensity was used to raise the bell pepper. Seeds of bell pepper cultivar 'Makong' were planted at $60 \times 60 \mathrm{~cm}$ spacing in $3.0 \times 3.0 \mathrm{~m}$ plot area. Recommended farmyard manure $\left(15 \mathrm{tha}^{-1}\right)$ was applied three weeks before transplanting and for the recommended inorganic fertilizers (120: 60 : $60 \mathrm{~kg} \mathrm{NPK} \mathrm{ha-1}$ ), full dose of phosphorus and potash along with half nitrogen were applied as basal and rest nitrogen was top dressed in two equal splits at 30 and 60 days after transplanting. Pinching of main shoot was carried out at one month after transplanting as per pruning treatments like two shoot, three shoot and four shoot levels. All agronomic practices were adopted timely for raising healthy crop. The observation were recorded for plant height $(\mathrm{cm})$, leaf area $\left(\mathrm{cm}^{2}\right)$, leaf chlorophyll (SPAD), days to marketable maturity, number of fruits plant ${ }^{-1}$, fruit weight $(\mathrm{g})$, fruit yield $\left(\mathrm{kg} / \mathrm{m}^{2}\right)$ and vitamin $\mathrm{C}\left(\mathrm{mg} 100 \mathrm{~g}^{-1}\right)$ content of the fruits. The chlorophyll content of the leaf was measured by portable chlorophyll meter (SPAD 502; Minolta, Japan). The vitamin C content was determined titrimetrically, using 2, 6 dichlorophenol indophenol dye as per method suggested by Ranganna (1986). The data collected on various parameters were statistically analyzed and treatment means were compared using least significant difference (LSD) test at 0.05 level of significance (Panse and Sukhatme, 2000). All analyses were performed using INDOSTAT version 8.0 statistical package.

\section{RESULTS AND DISCUSSION}

Effect of growing condition on growth and yield of bell pepper: The results (Table 1) revealed that growth and yield attributes of bell pepper ( Capsicum annuum L.) was significantly ( $5 \%$ level) influenced by the growing environment. Cultivation of bell pepper under agro shade net showed marked effect and recorded the highest plant height $(52.42 \mathrm{~cm})$ along with maximum leaf area $\left(5.61 \mathrm{~cm}^{2}\right)$ and leaf chlorophyll content (56.32 SPAD value). As a culmination of favourable vegetative growth the maximum number of fruits (11.18 plant $\left.^{-1}\right)$, highest fruit weight (111.12 g) along with greatest fruit yield $\left(1164.39 \mathrm{~g} \mathrm{plant}^{-1}\right.$ and $28.24 \mathrm{~kg} \mathrm{plot}^{-1}$ ) were obtained by the shade net grown bell pepper. The increasing numbers of fruits per plant and fruit yield per plant were $49 \%$ and $53 \%$, respectively over the open field cultivation. Bell pepper is highly sensitive to environmental stresses particularly temperature, humidity and light intensity. High day temperature along with higher night temperature $\left(24^{\circ} \mathrm{C}\right)$ prompted flower drop in bell pepper (Rylski and Halevy, 1974). Under shade net the temperature can be controlled partially and therefore healthy and better growth of plants can be expected under agro shade net cultivation. Again optimum relative humidity prevents evaporation losses from the plants and thereby increases the availability of net energy for crop growth, encourages optimum utilization of nutrients, promote activity of metabolic enzymes, maintain turgidity of the cells and prolong the survival of crop under moisture stress conditions (Reddy, 1999). The light intensity also influenced the crop performance as solar radiation consists of different wave lengths of light, in which only the visible portion is useful for crop growth, while ultra violet and infrared radiations are not beneficial for the crop growth, as they bring changes in molecular level which leads to cellular disorganization of the crops grown under open field condition (Zende, 2008). Partial light penetration in shade net house might have minimized the UV and infrared radiations and encourage better 
Chatterjee, R. et al. / J. Appl. \& Nat. Sci. 10 (3): 826 - 830 (2018)

Table 1. Effect of growing conditions, planting dates and pruning levels on growth, fruit yield and quality of bell pepper.

\begin{tabular}{|c|c|c|c|c|c|c|c|c|c|}
\hline Treatment & $\begin{array}{l}\text { Plant } \\
\text { height } \\
\text { (cm) }\end{array}$ & $\begin{array}{l}\text { Leaf } \\
\text { area } \\
\left(\mathrm{cm}^{2}\right)\end{array}$ & $\begin{array}{l}\text { Leaf c } \\
\text { rophyll } \\
\text { (SPAD) }\end{array}$ & $\begin{array}{l}\text {-Days } \\
\text { marketable } \\
\text { maturity }\end{array}$ & $\begin{array}{l}\text { toNumber } \\
\text { e of fruits } \\
\text { plant }\end{array}$ & $\begin{array}{l}\text { Fruit } \\
\text { s/weight } \\
\text { (g) }\end{array}$ & $\begin{array}{l}\text { Fruit } \\
\text { yield } \\
\text { plant }(\mathrm{g})\end{array}$ & $\begin{array}{l}\text { Fruit yie } \\
\text { /plot } \\
\left(\mathrm{kg} \mathrm{m}^{-2}\right)\end{array}$ & $\begin{array}{l}\text { //Vitamin } \\
\text { (mg/100g } \\
\text { fresh fruit) }\end{array}$ \\
\hline \multicolumn{10}{|c|}{ Growing conditions } \\
\hline $\mathrm{G}_{1}$ & 37.19 & 4.48 & 43.11 & 91.17 & 6.32 & 87.34 & 548.23 & 12.86 & 119.14 \\
\hline $\mathrm{G}_{2}$ & 52.42 & 5.61 & 56.32 & 99.43 & 11.18 & 111.12 & 1164.39 & 28.24 & 136.38 \\
\hline$C D(P=0.05)$ & 4.57 & 1.14 & 4.59 & 5.28 & 1.59 & 6.22 & 108.31 & 2.24 & 6.87 \\
\hline \multicolumn{10}{|c|}{ Planting dates } \\
\hline$\overline{D_{1}}$ & 56.32 & 5.79 & 59.31 & 102.64 & 14.38 & 116.32 & 1546.47 & 37.28 & 139.27 \\
\hline $\mathrm{D}_{2}$ & 51.28 & 5.37 & 53.64 & 99.38 & 11.21 & 112.39 & 1143.29 & 27.41 & 128.61 \\
\hline$D_{3}$ & 44.49 & 4.76 & 48.27 & 95.41 & 9.56 & 102.38 & 894.16 & 21.43 & 121.34 \\
\hline$D_{4}$ & 39.74 & 4.21 & 41.82 & 93.67 & 7.37 & 87.64 & 579.87 & 13.59 & 114.65 \\
\hline $\mathrm{CD}(\mathrm{P}=0.05)$ & 4.12 & 1.39 & 4.87 & 5.51 & 1.74 & 6.51 & 121.42 & 2.61 & 7.68 \\
\hline \multicolumn{10}{|c|}{ Pruning levels } \\
\hline $\mathrm{P}_{0}$ & 42.64 & 4.87 & 43.31 & 105.87 & 7.76 & 93.54 & 654.39 & 15.46 & 116.42 \\
\hline $\mathrm{P}_{1}$ & 45.31 & 5.19 & 46.56 & 101.41 & 9.76 & 101.37 & 896.84 & 21.34 & 122.18 \\
\hline $\mathrm{P}_{2}$ & 51.54 & 5.46 & 55.43 & 96.28 & 12.35 & 110.29 & 1234.18 & 29.31 & 134.28 \\
\hline $\mathrm{P}_{3}$ & 48.23 & 5.31 & 52.72 & 98.64 & 10.11 & 104.37 & 964.51 & 23.04 & 131.47 \\
\hline$C D(P=0.05)$ & 3.94 & 1.47 & 4.96 & 5.74 & 1.89 & 6.76 & 129.57 & 2.87 & 7.11 \\
\hline
\end{tabular}

Treatments: $G_{1}$-open field $G_{2}$-shade net house; $D_{1}-1^{\text {st }}$ February planting, $D_{2}-15^{\text {th }}$ February planting, $D_{3}-2^{\text {nd }}$ March planting, $D_{4}-17^{\text {th }}$ March planting; $P_{0^{-}}$no pruning, $P_{1}-2$ shoot pruning, $P_{2}-3$ shoot pruning and $P_{3}-4$ shoot pruning.

plant growth and yield. Naik (2005) with his experiment with bell pepper found that growth and yield of bell pepper was maximum under agroshed net. Similar results were also observed by Chatterjee and Mahanta (2014) in cauliflower who reported that presence of optimum temperature, humidity and light intensity favourably influence the growth and yield of cauliflower.

Effect of planting dates on growth and yield of bell pepper: A perusal of data (Table 1) depicted that different planting dates showed significant effect on growth and yield attributes of bell pepper. Planting of bell pepper on $1^{\text {st }}$ February resulted in highest plant height $(56.32 \mathrm{~cm})$ as well as leaf area $\left(5.79 \mathrm{~cm}^{2}\right)$ and leaf chlorophyll content (59.31 SPAD value). The same planting date $\left(1^{\text {st }}\right.$ February) emerged as best in terms of more number of fruits (14.38 plant $^{-1}$ ), maximum fruit weight $(116.32 \mathrm{~g})$ and highest fruit yield $\left(1546.47 \mathrm{~g} \mathrm{plant}^{-}\right.$ and $\left.37.28 \mathrm{~kg} \mathrm{plot}^{-1}\right)$. The result revealed that $1^{\text {st }}$ February planting produced $49 \%$ greater number

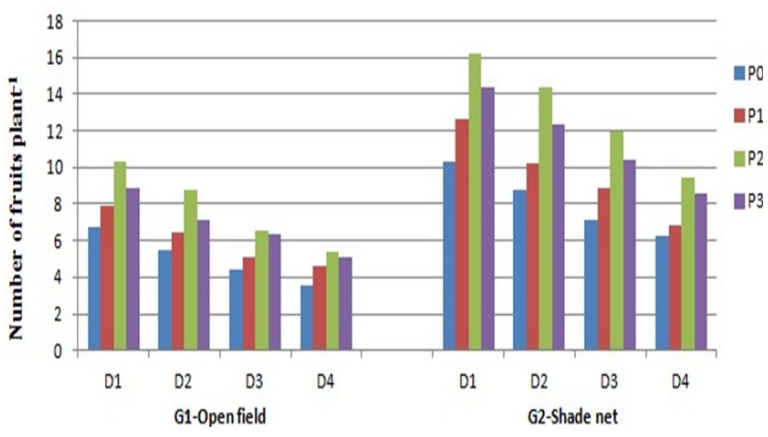

Fig.1. Interaction effect of growing condition, planting dates and pruning levels on number of fruits plant ${ }^{-1}$ of bell pepper (Treatment details are in Table 1). of fruits plant $^{-1}$ and $63 \%$ higher fruit yield plant ${ }^{-1}$ over $17^{\text {th }}$ March planting. This may be attributed to availability of favourable environmental condition for appropriate synchronization of flowering and subsequent transformation to fruit for producing optimum yield (Nahardani et al., 2013). Reduction in fruit set in delayed planting may be associated with decreased concentrations of reducing sugars in flower buds and flowers that may results failure of pollination and induce abscission of flowers under high temperature condition (Wien et al., 1989; Erickson and Markhart, 2001). Taskovics et al. (2010) also pointed that under high temperature condition fruit set becomes poor and less developed fewer fruits are produced. The planting dates also influenced the vitamin $C$ content of the fresh fruits and higher temperature range under late planting decreased the vitamin $\mathrm{C}$ content of the fruits. Pevicharova et al. (2007) also recorded lower amount of vitamin C content under higher temperature and stated that in bell pepper fruits high day temperature

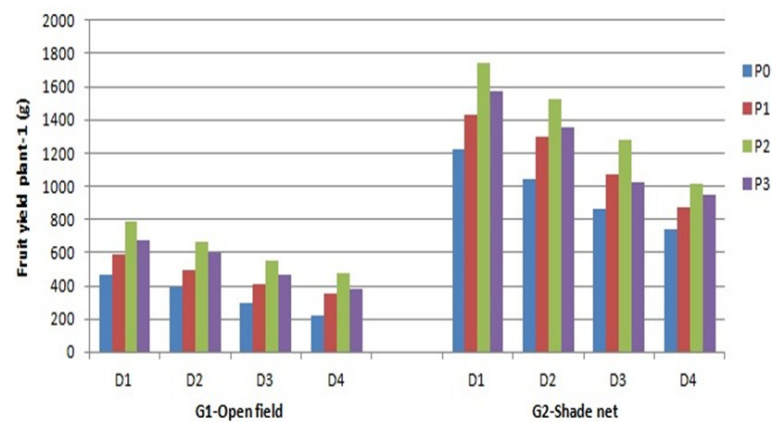

Fig. 2. Interaction effect of growing condition, planting dates and pruning levels on fruit yield plant ${ }^{-1}$ of bell pepper (Treatment details are in Table 1). 
decreased the total vitamin $C$ of fruits.

Effect of pruning level on growth and yield of bell pepper: The result (Table 1) revealed that different pruning levels have significant effect on the performance of bell pepper. Among different pruning levels, the 3 shoot pruning emerged as best and resulted in maximum plant height (49.20 $\mathrm{cm})$, leaf area $\left(5.46 \mathrm{~cm}^{2}\right)$, leaf chlorophyll content (55.43 SPAD value) along with highest number of fruits (12.35 plant $\left.^{-1}\right)$, maximum fruit weight $(110.29 \mathrm{~g})$ and total fruit yield $\left(1234.18 \mathrm{~g} \mathrm{plant}^{-1}\right.$ and $29.31 \mathrm{~kg} \mathrm{plot}^{-1}$ ). The better response by 3 shoot pruning level may be due to the optimum number of shoots which utilized the resources like water, nutrients, light etc. and accumulated photosynthates very efficiently compared to other pruning levels. Positive response of pruning in bell pepper (Capsicum annuum L.) was reported by Cebula (1995), Elio et al. (1998) and Dasgan and Abak (2002).

Effect of interaction of growing condition, planting dates and pruning levels on growth and yield of bell pepper: The findings indicated a significant interaction between growing condition, planting dates and pruning levels on the growth and yield attributes of bell pepper. Cultivation of bell pepper in shade net along with planting on $1^{\text {st }}$ February and maintaining 3 shoot pruning had exerted highest plant height as well as leaf area and leaf chlorophyll content. The same combination also recorded highest number of fruits (16.21 plant $^{-1}$ ) and fruit yield (1743.21 plant $^{-1}$ ) which were significantly higher over all other treatment combinations (Fig 1 and 2).

The result showed that favourable environment coupled with optimum planting time and right pruning level had more positive impact on growth, yield attributes and quality of bell pepper. Thanopoulos et al., (2013) observed that the growth and size of bell pepper fruits were highly influenced by air temperature, daylight and relative humidity particularly during anthesis, fruit set, fruit development and maturation stages. Cultivation of bell pepper cv. Mekong under favourable planting date had emerged as highly efficient in production and translocation of assimilates to the developing sink and accelerated the formation of more fruits and subsequently produced higher fruit yield.

\section{Conclusion}

The experimental results demonstrated that bell pepper (Capsicum annuum L.) cultivation under agro-shade net had faster plant growth, better fruit yield and quality attributes as compared with the uncovered open field plants. Adoption of shade net cultivation along with planting on $1^{\text {st }}$ February and maintaining three shoot pruning will help to achieve desirable growth and yield attributes and will augment the performance of bell pepper during off season.

\section{REFERENCES}

1. Baruah T.C. and Barthakur H.P. (1997). A Text Book of Soil Analysis. Vikas Publishing House Pvt Ltd. India

2. Cebula, S. (1995). Optimization of plant and shoot spacing in greenhouse production of sweet pepper. Acta Hort., 412: 321-328.

3. Chatterjee, R. and Mahanta, S. (2013). Performance of off-season cauliflower (Brassica oleracea var. botrytis L.) under agro shade net as influenced by planting dates and nutrient source. Int. J. Adv. Agril. Sci. Tech., 1(1): 56-62.

4. Dasgan, Y.H. and Abak, K. (2003). Effects of planting density and number of shoots on yield and fruit characteristics of pepper grown in glasshouse. Turkish $\mathrm{J}$. Agric. For., 27: 29-35.

5. Erickson, A.N. and Markhart, A.H. (2001). Flower production, fruit set and physiology of bell pepper during elevated temperature and vapor pressure deficit. J. American Soci. Hort.. Sci., 126(6): 697-702.

6. Elio, J., Daniel, J, Cantliffe and George J.H. (1998). Plant density and shoot pruning on yield and quality of a summer greenhouse sweet pepper crop in north central Florida. Retrieved from www.northcentralfloridapepper.com

7. Nahardani, A.A., Sinaki, J.M, Firouzabadi, M.B. and Abbaspour H. (2013). Effects of sowing date and biological fertilizer foliar on yield and yield components of cowpea. Int. J. Agron. Plant Prod., 4 (11): 2822-2826.

8. Naik, R.K. (2005). Influence of N-substitution levels through organic and inorganic sources on growth, yield and post-harvest quality of capsicum under protected condition. Ph. D. Thesis, UAS, Dharwad, Karnataka, India.

9. Jovicich, E., D.J. Cantliffe, J., VanSickle, and P. Stoffela. (2005). Greenhouse grown colored peppers: A profitable alternative for vegetable production in Florida. Hort Technology 15:355-369

10.Jackson, M.L (1967). Soil chemical analysis. Prentice Hall of India Pvt. Ltd; New Delhi. Jackson, M.L. (1973). Soil chemical analysis. Prentice Hall, New Delhi.

11.Panse, V.G. and Sukhatme, P.V. (2000). Statistical methods for agricultural workers. ICAR Publications, New Delhi, India.

12.Pevicharova, G., Todorova, V. and Todorov, J. (2007). Ascorbic acid and total sugars content of Kapya type pepper depending on cultivars and climatic conditions. Rasteniev-dni-Nauki, 44(1): 52-56.

13.Piper, C. S. (1950). Soil and Plant Analysis, The University of Adelaide Press, Adelaide, Australia, $368 p$

14.Ranganna, S. (1986). Analysis and quality control for fruits and vegetable product. Tata McGraw- Hill Publishing Company Ltd. New Delhi, India.

15.Reddy, S.R. (1999). Principles of Agronomy, Kalyani Publishers, New Delhi, pp. 25-28.

16.Rylski, I. and Halevy, A. H. 1974. Optimal environment for set and development of sweet pepper fruit. Acta Hort., 42: 55-62.

17.Taskovics, Z.T., Orosz, F. and Kovacs, A. (2010). The effect of some environment factors on the growth of sweet pepper. Acta Universitatis Sapientiae- Agri. Env., 2: 17-22.

18.Thanopoulos, C., Akoumianakis, K. and Passam, H. 
(2013). The effect of season on the growth and maturation of bell peppers. Int. J. Plant Prod.,7(2):279-294

19.Turner, A.D. and Wien, H.C. (1994). Photosynthesis, dark respiration and bud sugar concentrations in pepper cultivars differing in susceptibility to stressinduced bud abscission. Ann. Bot., 73: 623-628.

20.Walkley A. and Black J A. (1934). An estimation of the Degtjareff method for determining soil organic matter and proposed modification of the chronic acid titration methods. Soil Science. 37: 27-28.
21.Wien, H.C., Tripp, K.E., Armenta, H.R. and Turner A.D. (1989). Abscission of reproductive structures in pepper: causes, mechanisms and control. In: Green, S.K. (Eds.) Tomato and pepper production in the tropics. R.O.C: Asian Vegetable Research and Development Center, Taipei, Taiwan, pp. 150-165.

22.Zende, U.M. (2008). Investigation on production techniques in capsicum under protected cultivation. M.Sc. Thesis, UAS, Dharwad, Karnataka, India. 